\title{
A monograph of the genus Calostoma, Desv. (Mitremyces, Nees).
}

BY

GEORGE MASSEE.

With Plate III.

\section{MORPHOLOGY.}

$\mathrm{T}^{\mathrm{H}}$ $\mathrm{HE}$ presence in the Royal Herbarium, Kew, of a fine series of specimens representing the various stages of growth in Calostoma cinnabarinum, Desv. (Mitremyces lutescens, Schw.), from $8 \mathrm{~mm}$. in diameter to the mature stage, has enabled me to follow the course of development from the period of differentiation of the gleba to that of dehiscence. The smallest specimen is spherical, $8 \mathrm{~mm}$. across when dry, not at all attenuated towards the base, of a pale red colour, and covered with a hard, thin, translucent, wrinkled coat; which after soaking for some time in water became very much swollen and mucilaginous (Fig. 1), and on removal from the water broke away in fragments, appearing under the microscope as a structureless, colourless mass, with the exception of a thin ill-defined peripheral portion of interwoven hyphæ with thick mucilaginous walls, which, becoming more compact at the base, form there a short stem persisting after the disappearance of the upper portion.

The above structure is in every respect homologous with the peridium in the Phalloideae, but differs in being entirely deliquescent at an early period; hence no trace of its presence is to be seen in mature specimens. Its appearance as studied in the living condition is described as follows by the Rev.

[Annals of Botany, Vol. II. No. V, June 1888.] 
Edward Hitchcock in a paper, containing many points of interest, relating to the development of the present species: 'On bursting from the soil it is enclosed in a gelatinous envelope, like Phallus foetidus, nearly a quarter of an inch in thickness. This immediately bursts, even before the whole body of the fungus has risen above the ground, and the exterior part of it falls upon the soil around the fungus in the form of a viscid jelly, and is ere long absorbed in the earth ${ }^{1}$.'

The short stem-like base arises from a few firm, white, mycelium strands composed of thin-walled, sparsely septate, branched hyphæ about $4 \mu$ in diameter, the free tips bristling with minute amorphous particles of oxalate of lime. After removal of the external gelatinous volva, a vertical section shows an external colourless zone about $\mathrm{I} \mathrm{mm}$. thick, separated from the internal portion except at the base by a thin red line (Fig. 2). The outermost zone is composed of thick-walled mostly aseptate densely interwoven hyphæ, passing through the red zone into the central less-compact portion, where they are mixed with thin-walled, septate, branched hyphæ, having numerous slightly thickened free tips.

A second specimen, $\mathrm{I} .5 \mathrm{~cm}$. in diameter, is spherical in form, with a small obtuse umbo at the apex and abruptly attenuated below into a thick stem-like base about $0.5 \mathrm{~cm}$. long, every external part being smooth and of a bright vermilion colour. The only evidence of the external gelatinous volva consists in the presence of an irregular cartilaginous ridge near the base of the stem.

When dry the plant is rigid and cuts like horn; a median vertical section in this condition shows the external wall to consist of three distinct layers, the two outermost confluent at the base, the innermost free below but in contact with the middle layer at the umbonate apex. The external layer or exoperidium is at first continuous over every part of the

1 Physiology of the Gyropodium coccineum, by the Rev. Edward Hitchcock, in Sillim. Amer. Journ. vol. ix (1825), p. 56, pl. iii. 
plant, about $\mathrm{I} \cdot 5 \mathrm{~mm}$. thick when dry, except at the apex where it is thinner, and increasing to $3-4 \mathrm{~mm}$. when placed in water.

The red streak present in the small specimen is now seen to form the innermost portion of the exoperidium, and at the present stage of development exists in the form of red powder. In the earlier condition the cells forming the red zone are thick-walled, the substance of the walls being studded with numerous small red granules. Eventually the walls of the cells constituting this zone become mucilaginous and disappear, leaving the red granules in the form of a fine powder, thus effecting the separation of the exoperidium from the originally homogeneous spherical weft of hyphæ. The innermost portion of the exoperidium consists of compactly interwoven thick-walled hyphæ about $8 \mu$ thick, not at all mucilaginous, and furnished with a few red granules which become rarer towards the outside and eventually disappear; the hyphæ at the same time becoming thinner and thinner owing to the diffluent walls, and at the outside entirely converted into a homogeneous mucilaginous jelly.

When a section of the exoperidium has been soaked for some time in water, the thin hyphæ forming the outer portion are straight, the principal branches more or less parallel and growing out towards the periphery after the manner of the palisade-tissue of a leaf, but not at all crowded and frequently anastomosing. Septa and clamp-connections are present. If a section is allowed to dry slowly under the microscope the external gelatinous portion contracts, the small hyphæ at the same time becoming spirally coiled, straightening out again on the application of water.

The red colouring matter is soluble in ammonic or potassic hydrate, agreeing in this respect with the colouring substances in Corticium caenuleum, $C$. sanguineum, and in the fungal element of many lichens. Owing to a slight increase in length of the basal portion between the exoperidium and endoperidium, and continued increase in size of the latter, the exoperidium is ruptured at the apex in an irregularly 
stellate manner, the lobes when moistened curling inwards owing to expansion of the external mucilaginous portion, and soon breaking away at the base. The rupture of the exoperidium is described by Hitchcock as follows: 'A specimen dissected in a young state exhibits this envelope covering every part of the spherical head, with no seam discernible in it, but ere long it opens at the top, beginning to separate into numerous divisions or rays, like the opening calyx or petals of a common flower. Several valves on the top of the plant, opening into its head, are thus disclosed. A portion of the jelly, often $\frac{1}{10}$ of an inch thick, adheres to these calyx-like divisions of the envelope now under consideration, and as the inner part of it is very tender, they rarely become much expanded before they begin to coil inwards and break off at the base; merely from their weight they drop to the ground, or as is more usual adhere to the footstalk ${ }^{1}$ '

Several specimens in the Kew Herbarium show this apical splitting of the exoperidium, which is however sometimes ruptured in a circumscissile manner at or near the base, the margin splitting into irregular teeth as represented in an exaggerated manner by $\mathrm{Nees}^{2}$, who selected the name Mitremyces as expressive of the mitriform exoperidium or calyptra as it is called by Berkeley. One specimen of $C$. cinnabarinum and one of C. fusca (Fig 24a) in the Kew Herbarium illustrate this mode of rupture, which is probably abnormal, as in each specimen the spores are quite mature, but prevented from escaping owing to the persistent exoperidium. In most species the exoperidium becomes completely disorganised, often remaining in the form of warts on the endoperidium, as in many species of Lycoperdon. When dry the endoperidium is cartilaginous and brittle, of a dirty ochraceous colour and less than $\mathrm{I} \mathrm{mm}$. thick, becoming much swollen when moistened. When young it consists of thick-walled, closely compacted hyphæ more or less gela-

1 l. c. p. 57.

${ }^{2}$ Pilze und Schwämme, T. 11, f. 129, a. 
tinous, and must be considered as homologous with the collenchyma-layer in Geaster. At a later stage the thick walls become disorganised, when a section presents the appearance of a loose weft of hyphæ not more than $2 \mu$ thick imbedded in a homogeneous mucilaginous matrix, but in reality the apparent hyphæ are the lumina of the original thick-walled cells, or more correctly the few remaining contents of the cells, as on staining with iodine the apparent hyphæ are seen to consist of minute granules forming a broken line; and from this appearance every transition can be observed in young specimens to the clearly defined thick-walled cells. Even in old specimens where the mucilage appears perfectly homogeneous in water, if the latter is replaced by alcohol, and iodine solution afterwards added, the outlines of the swollen walls are seen, owing to the accumulation of iodine in the interstices between adjoining cells, the mucilage itself undergoing no change in colour.

When young the wall of the endoperidium is of equal thickness throughout, but during the period of spore-formation, local growth takes place at the apex, resulting in the formation of an excrescence or umbo of cylindrical form, from $2-3 \mathrm{~mm}$. high and the same across. The circumference of the umbo is furnished with from 5-7 deep vertical furrows situated at equal distances, so that when viewed from above the umbo presents the appearance of a 5-7-rayed star, the rays starting from a boss-like centre. At this stage a fine red streak appears in the median line of each vertical ridge separating the furrows; these streaks are continued along the apical portion of the ridge and meet in the boss-like centre. A transverse section shows that the streaks extend through the entire thickness of the wall and form a central core down the umbo, the component hyphæ undergoing disintegration similar to that already described in the red zone between the exoperidium and endoperidium. This process results in the formation of an aperture or mouth, the surrounding teeth (which are subquadrate in form with a depressed central line corresponding to a groove on the 
wall of the umbo) remaining in apposition until the period of dehiscence, when by a process to be afterwards described, separation of the teeth takes place, the margins and inner surface of each being covered with red powder.

The endoperidium, as already stated, is not differentiated from the exoperidium at the base. There is no trace of a columella springing from the basal portion of the inner wall of the endoperidium. The innermost layer or spore-sac is at first composed of hyphæ similar to and continuous with those of the endoperidium, its external delimitation being due to gelification of the latter, the hyphæ of the spore-sac remaining unchanged. The wall is about $.5 \mathrm{~mm}$. thick, yellowish white in colour, flexible, and perfectly free from the endoperidium except at the apex, where it remains attached to the inner surface of the teeth; but even here it is completely differentiated, and after soaking, by the exercise of a little care it can be entirely separated, when it resembles the mouth of the inner peridium in Geaster, the teeth being very delicate and continuous with an external circular depression in the substance of the spore-sac corresponding to the portion in contact with a zone below the teeth of the endoperidium. The hyphæ on passing into the spore-sac become thinner and are loosely felted, mostly aseptate, but a few sparsely septate branches occur. During the period of spore-formation the central mass or gleba is continuous with the inner wall of the spore-sac, and consists in an early stage of densely wefted trama-like bands enclosing irregular cavities as described by Fischer ${ }^{1}$ in Sphaerobolus, but the development of this portion can only be satisfactorily studied in a complete series of living plants. The basidia are broadly obovate, measuring from $40-50 \times$ I $5^{-20} \mu$, and bear five or sometimes six spores supported on minute wart-like prominences arranged in a circle round the apex (Fig. 14a). The spores are at first globose, smooth, and

1 Zur Entwickel. der Gastromyceten (Sphaerobolus and Mitremyces), in Bot. Zeitg. $188_{4}$. 
colourless, becoming eventually elliptical from $\mathrm{I} 5$-I $8 \times 8$-10 $\mu$, of a pale ochraceous tint, and minutely warted (Fig: I5).

When the spores are ripe, the basidia and hyphæ forming the trama become mucilaginous, the septate hyphæ breaking up into detached cells, which before complete disorganisation become very much swollen, and probably correspond to the vesicular mucilage-cells described by Fischer as occurring in the gleba of Sphaerobolus. The disorganisation extends to within about $.5 \mathrm{~mm}$. of the outside of the spore-sac, which now appears as a sharply defined membrane everywhere up to. this period in contact with the inside of the endoperidium, but after the above-mentioned changes in the gleba contracts into a sphere less than $\mathrm{I} \mathrm{cm}$. in diameter, attached to the apex of the endoperidium immediately below its closed mouth. The contraction of the spore-sac is due to the peculiar behaviour of certain thick-walled hyphal constituents fixed at the point where it is attached to the teeth surrounding the orifice. These hyphæ after becoming sticky, contract in an irregular spiral manner, and draw the spore-sac with its contents up to the summit of the endoperidium. These contracted hyphæ remain for a long time unchanged in water, but if placed in dilute potassic hydrate soon begin to expand and reveal their true nature (Figs. 16, I7). There is no trace of a capillitium. The mucilage resulting from disintegration of the hyphæ contracts into irregular-shaped masses, leaving the spores perfectly free and dry in the spore-sac. The functional value of the various parts in connection with spore-dissemination can only be determined from an examination of living plants.

In several old specimens the spore-sac with its contents has completely disappeared from the endoperidium, and in two examples has passed through the mouth and remains attached to the teeth of the endoperidium as in Sphaerobolus. This extension of the spore-sac has been observed by Hitchcock and Berkeley, and may be considered as the normal mode of dehiscence, but sometimes the dry spores are forced out of the mouth without extension of the spore-sac, as described by 
Hitchcock. When the dried plant is placed in water up to the mouth without allowing the inside to become wet, the endoperidium contracts from the base upwards, the teeth at the same time separating and exposing a large aperture. Until the spores are ripe the stem-like base remains small, afterwards increasing to $5-6 \mathrm{~cm}$. in length by $1^{\circ} 5^{-2} \mathrm{~cm}$. across, and then consists of yellowish cord-like strands of hyphæ forming a complicated mucilaginous weft when moist.

The remaining species agree in all essential points of structure with $C$. lutescens. There is no evidence of the presence of a capillitium in any species, the threads described by Berkeley as being present in the spore-sac of $C$. lurida prove on examination of the original specimens to be fragments of the trama that have not become disorganised, owing to the plant being immature when collected. The spore-sac of $C$. Ravenelii is described by the same author as 'entirely filling the cavity of the second peridium ',' but this is only true of the young plant, in which it agrees with all known species; an examination of a mature specimen shows the spore-sac contracted at the apex of the endoperidium. Berkeley was aware that when young the spore-sac filled the endoperidium, as in speaking of the structure of $C$. lutescens the following statement occurs: 'The inner peridium .... in an early stage clearly lines the outer, and the void space arises from its ceasing to grow sooner than the outer ${ }^{2}$.'

In all species, every part of the plant with the exception of the spore-sac is perfectly rigid and cartilaginous when dry; every part with the exception of the inner surface of the endoperidium becoming swollen and more or less mucilaginous when moistened, which probably corresponds to the state of things in the living state.

The genus Husseia was established by Berkeley ${ }^{3}$ from an examination of two specimens sent by Gardner from Ceylon in 1846 , and he makes the following remarks on its affinities:

1 Trans. Linn. Soc. vol. xxii. p. I 30.

2 Ann. Nat. Hist. vol. iii. p. $3^{2} 5$.

${ }^{3}$ Hook. Lond. Joum. Bot. vol. vi. p. 508, t. I7, I8, fig. 3 , a, b; t. 19, fig. I, a. 
'This genus externally resembles Mitremyces, but not only is the covering of the peridium viscoso-cartilaginous, and reflected in the form of a veil, instead of falling off like a calyptra, but the capillitium exactly fills the cavity, the outer portion consisting of a barren stratum of coloured flocci, and the spores instead of being elliptic are globose and coarsely echinulate. The inner peridium is clearly represented by the barren flocci which form a dense lining to the cavity.' Both plants are figured on the plate quoted, one being immature with the exoperidium continuous, the other having the exoperidium ruptured and persistent on the stem at some distance below its apex, and the spore-sac has disappeared from the endoperidium. The immature specimen has been cut open, and shows the spore-sac filling the endoperidium.

In 1868 several more specimens of the same species were sent to Berkeley from Ceylon, one having the spore-sac extended and remaining attached to the mouth of the endoperidium (Fig. $3^{8} a$ ); two others show the spore-sac contracted as in Calostoma. In some specimens the stem is cylindrical, in others ventricose and slightly lacunose. The exoperidium has in every instance disappeared from the stem.

The genus Husseia was established before the globosespored forms of Calostoma were known; but as there are now four described species of these, one of the three points of distinction between Husseia and Calostoma (Mitremyces) disappears ; and a second relating to the spore-sac filling the cavity of the endoperidium, being only true of the immature condition, also is invalid; whilst the third point of difference supposed to be afforded by the texture and mode of rupture of the exoperidium has its homologue in Calostoma cinnabarinum.

The structure of Husseia agrees in every essential point with that of Calostoma. The presence of the ruptured exoperidium attached half-way down the stem is due to increase in length of the tissue between the endoperidium and exoperidium during and after the rupture of the latter. Numerous 
Massee.-A monograph of

clusters of aciculate crystals of oxalate of lime are present in the gleba (Fig. 40), and are alluded to by Berkeley as follows : 'Some parts of the flocci have at tolerably regular intervals little fascicles of bristles, the nature of which I cannot determine.'

The above statement explains why Husseia insignis has been placed in the genus Calostoma in the following arrangement. All the species referred to still exist in an excellent state of preservation in Berkeley's herbarium at Kew.

\section{AfFinities.}

Calostoma is morphologically most nearly related to the genus Geaster, the homology in many respects being absolute, the differences at the same time extreme. The external peridium of Geaster, which splits in a stellate manner when ripe, corresponds to the exoperidium and endoperidium in Calostoma, the inner peridium in Geaster being the morphological equivalent of the spore-sac in Calostoma. The outer flakey layer of Geaster, which is more or less mucilaginous in most species when young, as proved by the presence of numerous foreign particles in its substance, represents in a reduced form the universal gelatinous volva of Calostoma. The thick brown continuous layer of Geaster represents the exoperidium of Calostoma, and finally the collenchyma-layer of Geaster corresponds to the endoperidium of Calostoma.

In Geaster the morphological equivalents of the exoperidium and endoperidium in Calostoma usually remain in contact and break away as one membrane, but there are exceptions. In Geaster triplex, Jungh., the thick brown layer splits from the apex in a stellate manner, the rays becoming reflexed, whereas the collenchyma-layer remains in the form of a cup enclosing the inner peridium like the endoperidium in Calostoma. In Geaster fornicatus, Fr., the brown layer and collenchyna-layer remain in contact until after splitting into rays, when the latter separates and becomes strongly arched 
upwards, remaining in contact with the brown layer at the tips of the rays. A young unexpanded Geaster is more or less globose and furnished at the apex with a prominence or umbo, as in Calostoma. A vertical section at this stage shows the external brown layer to be continuous over the apex, whereas the umbonate portion of the collenchyma-layer is fluted, as in the endoperidium of Calostoma.

The fluted appearance of the umbo in Geaster is due to what might be described as puckering, extending through the entire thickness of the substance, the external ridges producing corresponding internal furrows. At this period the umbo and upper portion of the inner peridium are differentiated from, but in intimate contact with, the inside of the collenchymalayer, and are as it were modelled into form during the differentiation of the latter, the external configuration of the mouth and depressed area circumscribing it, resulting, as in Calostoma, from external pressure. In Geaster the inner peridium is confluent at the base with the collenchyma-layer, in some species sessile, in others elevated on an elongated stem. This feature constitutes the most pronounced structural difference between the present genus and Calostoma. Points of minor importance are the presence of a more or less prominent columella and capillitium in Geaster.

Professor de Bary, in pointing out the connection between the Phalloideae and the rest of the Gastromycetes, says: 'The connection between Clathrus and Geaster appears to me to be still more completely established by the genus Mitremyces, which is chiefly American and still far from being thoroughly known. But I do not attempt to describe it here, for I have no sufficient account before me of the history of its development '.'

This idea, which suggested the present attempt to trace the affinities of the genus under consideration, is in the main correct, although the intermediate forms necessary to prove true relationship between Calostoma and Phalloideae are not at

1 Fungi, Mycetozoa and Bacteria, Engl. ed. p. 326.

D 2 
present forthcoming, hence there is the danger of confounding analogous with homologous structures. Colus hirundinosus, one of the Phalloideae described in detail by Tulasne ${ }^{1}$, appears to approach Calostoma most nearly in structure. This species when young is enclosed in a universal volva which is ruptured by continued growth of the receptaculum. This receptaculum is certainly analogous, if nothing more, to the endoperidium in Calostoma, surrounding the gleba, which at maturity contracts and remains suspended from the apex. The receptaculum, which is at first sessile, is not furnished with a mouth at the apex, but its lateral wall has several long slits, and the apical portion is also perforated, thus furnishing an efficient arrangement for spore dissemination by rain or insects. In the allied genera Clathrus and Ileodictyon the receptaculum at maturity resembles a sphere composed of large irregular meshes surrounding the gleba, its obvious function being that of placing the latter in the most favourable position for the diffusion of the spores, in which it agrees with the endoperidium in Calostoma, although in the latter this is effected in a different manner, as already described.

\section{iII. Distribution.}

Although the species are, with two exceptions, restricted to narrow areas, the genus is widely distributed, extending from Massachusetts $\left(42^{\circ} \mathrm{N}\right.$. lat.) to the south of Tasmania $\left(42^{\circ} \mathrm{S}\right.$. lat.), and from New Granada $\left(74^{\circ} \mathrm{W}\right.$. long.) to Tasmania ( $174^{\circ} \mathrm{E}$. long.), with a vertical range from near the sea-level to 9000 feet in the Sikkim Himalayas.

The species are divided into two natural groups characterised by the form of the spores. An eastern group, including six species with globose spores, of which $C$. Funghuhni may be considered the type, are distributed as follows :-C. Funghuhni, Java, Sumatra, Ceylon, Sikkim Himalayas (8000 feet); C. Berkeleyi, Ceylon, south of the island; C. orirubra, Larut, Perak, Malay Peninsula; C. viridis, Tonglo and Sinchal,

\footnotetext{
${ }^{1}$ Scient. Expl. d'Algerie, Fungi, p. 435, t. 23, figs. 9-2 2.
} 
Sikkim Himalayas (7000-9000 feet); C. insignis, Ceylon; C. brachystelis, Borneo and Ceylon.

The western group includes four species with elliptical spores, of which $C$. cinnabarinum is the type; distributed as follows:-C. cinnabarinum, east side of the United States, from Massachusetts to Carolina, New Granada, C. Ravenalii, Mountains of South Carolina; $C$. fusca, Tasmania and S. Australia ; C. Lurida, Australia (Swan River).

The close relationship of the Australian and Tasmanian with the American species has its parallel in the genus Ileodictyon, including two species not uncommon in South Australia and Tasmania, one of which, $I$. cibarius, has been received by Berkeley from Chili, and I have collected the same species in Ecuador at about 6000 feet elevation.

\section{ClaSSIFICATION.}

Calostoma, Desv.

Exoperidium continuous, eventually irregularly ruptured. Endoperidium furnished with an apical toothed ostiolum. Spore-sac when young filling the endoperidium, afterwards contracting towards the apex and remaining attached to the teeth of the ostiolum. Stem composed of agglutinated cordlike strands, forming irregular reticulations or lacunae.

Calostoma, Desvaux, Journ. de Bot., vol. ii. (1809), p. 94.

Mitremyces, Nees, Pilze und Schwämme (1817), p. 136.

Gyropodium, Hitchcock, in Silliman's Amer. Journ. Sc., vol. ix. $(1825)$, p. 56.

Scleroderma, Pers. in Desv. Journ. de Bot., vol.ii.(1809), p. I5. Lycoperdon, Bosc, in Berl. Mag., vol. v. p. 87.

The absence of information respecting the universal volva in other species than C. lutescens forbids it forming part of the generic diagnosis; nevertheless, judging from the monotypic structure of all known species in the mature condition, it may reasonably be assumed as common to all.

The remarkable diversity of appearance presented by C.cinnabarinum, Desv. (Mitremyces lutescens, Schw.) during different 
periods of development has been the cause of several mistakes; even Schweinitz did not know the plant in the young condition, as proved by the following statement in his Syn. Fung. Amer. Bor. in Amer Phil. Soc., I 83 I, p. 255 :-

' I. $M$. lutescens, L. v. S., Syn. Car. 345 ; Sprengel, p. 5 I 8 , rarius occurrit in Pennsylvania quam in Carolina, tamen passim.

'2. $M$. cinnabarinum (Calostoma), Desvaux et Brongniart, Bethl. et New York. Satis affine Mitremyci-sed peridium externum, corneum, coccineo-cinnabarinum, primum omnino clausum, demum deciduum et revolutim fissum in lacinias. Stipite prioris.'

It is evident that the above new species of Schweinitz is the young condition of his own $M$. lutescens. It is not quite clear whether the above specific character is original or a quotation; if the latter, I have not been able to trace it. Further, Schweinitz does not appear to have been acquainted with Desvaux' original generic diagnosis, or that of the species ( $M$. lutescens, Schw.) on which it was founded, as Brongniart is not mentioned in any way. The following is the description as given by Desvaux ${ }^{1}$ :-

- Calostoma, Sclerodermate spec., Pers.

'Pediculus coriaceus, lacunoso-clathroideus ; peridium globosum, cortice duplici; exteriore coriaceo, apice aperto dentato persistenti, dentibus marginato-reflexis appropinquatis ; cortice interiore tenuissimo, pulvere copioso luteo filis multis intermixto.

- Calostoma cinnabarinum, Scleroderma calostoma, Pers. page $I_{5}$ du $2^{\mathrm{o}}$ vol. de cet ouvrage, pl. 2 , fig. 2.

'Pediculo.lacunoso; peridio globoso dilute purpureo,4-7 dentato.

' Habitat in America boreali, supra terram.

'Obs. Cette plante est quelquefois décolorée, lorsqu'elle a été desséchée sans précaution, parceque sa couleur, qui est seulement extérieure et ne pénètre point dans le tissu de l'écorce, extérieure du péridie, est formée par une espèce de Pruine rouge, susceptible de se détacher.'

1 Observations sur quelques genres à établir dans la famille des Champignons, par N. A. Desvaux, Jounal de Botanique, vol. ii. pp. 94-95. 
The above incontrovertibly proves that the plant described by Desvaux is the same as Mitremyces lutescens, Schw.; hence Calostoma, having priority, must replace Mitremyces.

Persoon's figure quoted by Desvaux is very characteristic of the plant intended, whereas the same cannot be said for the figure of Nees, which does not represent a real plant, yet, as the species of this genus are not generally known to mycologists, a preconceived idea is formed from the last-named figure.

Calostona Funghuhni (Schl. et Müll.), Mass. Plate III, Fig. 21.

Exoperidium ochraceous, with sometimes a greenish tinge, soon breaking up into irregular warts, which persist for some time on the broadly elliptical ochraceous endoperidium, mouth vermilion, teeth $4-6$, erect at first. Spore-sac pale, spores globose, coarsely tuberculose, pale ochre, I4-I $8 \mu$ diameter, stem-like base composed of more or less parallel mycelial cords above, ending in a thickened mass of finer interwoven strands.

Mitremyces Funghuthni, Schlechtendal et K. Müller, in Bot. Ztg. 1884 , p. 40 I, Taf. iii. B. ; Sacc. Syll. v. 7. n. 204.

M. Beyrichii, Sch. et Müll., l.c. Java (Junghuhn), Sumatra (Junghuhn), Sikkim Himalayas, 8000 feet (Dr. G. King).

Variable in size, endoperidium $\cdot 5-\mathrm{I} \cdot 5 \mathrm{~cm}$. high; stem-like base $\mathrm{I}-2 \mathrm{~cm}$. long. In some specimens the warts of the exoperidium are persistent, in others disappearing at an early stage of development, leaving the endoperidium smooth externally.

Calostoma Berkeleyi, Mass., n. sp. Plate III, Fig. 33.

Exoperidium ochraceous externally, inside reddish brown, ruptured irregularly at the apex and breaking away, leaving the subglobose, ochraceous endoperidium smooth; ostiolum vermilion, teeth 5 , acute, erect. Spore-sac pale, spores globose, minutely verruculose, very pale ochre, 7-9 $\mu$ diameter, stemlike base ochraceous, irregularly lacunose.

Mitremyces lutescens, Schw., Berk. in Herb. (Type in 
Herb. Berk. Kew, n. 4472). Ceylon, south side of the island (Gardner, n. 673).

Superficially resembling $C$. lutescens, to which species it was referred by Berkeley and Broome in their enumeration of the fungi of Ceylon in Linn. Soc. Journ. vol. xiv. p. 78 , but readily distinguished by the globose spores. It differs from C. Funghuhni in the smaller and less coarsely warted spores and in the structure and colour of the exoperidium.

Calostoma orirubra, Cooke. Plate III, Fig. $3^{\text {I. }}$.

Fasciculate. Exoperidium dark brown, soon broken up into large persistent pointed warts. Endoperidium broadly ovate or elliptical, ostiolum vermilion, teeth 4-5, erect and forming a cone before expansion. Spore-sac pale ochre, spores spherical, coarsely tuberculate, very pale ochre, $\mathrm{I}_{4}-17 \mu$ diameter. Stems confluent, forming a subglobose lacunose brown mass.

Mitremyces orirubra, Cke. in $\mathrm{Hb}$. Kew. (Type in Hb. Kew.) In a cluster on the ground. Larut, Perak, Malay Archipelago. (Dr. King.)

Endoperidium $1-1.5 \mathrm{~cm}$. high, studded with prominent brown-pointed warts. Growing in -clusters of three or four together, the confluent stems forming a knob $2-3 \mathrm{~cm}$. across. A very distinct species, most nearly allied to $C$. Funghulhni.

Calostoma viridis (Berk.), Mass. Plate III, Fig. 29.

Exoperidium in the form of dingy green irregular scales adhering to the subglobose pale green endoperidium, ostiolum vermilion, teeth $5-7$, sub-acute, erect and forming a cone before expansion; spore-sac pale, spores globose, closely tuberculose ; very pale ochre, I2-I $5 \mu$ diameter. Stem-like base, stout, greenish, irregularly lacunose.

Mitremyces viridis, Berk., in Hook. Kew Journ. Bot. vol. iii. (1851), p. $20 \mathrm{I}$; Ic. Plant. pl. 869, f. B. (type in Hb. Kew); Sacc. Syll. v. 7. n. 207 . On the ground and on dead timber. Tonglo and Sinchul, Sikkim Himalayas, 7-900o feet. May, June, rare. [Dr. (now Sir Joseph) Hooker, with fig.]

A very beautiful and well-marked species, the whole plant 
of a dull green colour. Endoperidium about $2 \mathrm{~cm}$. in diameter. Stem $2 \mathrm{~cm}$. or more long by $\mathrm{I}-\mathrm{I} \cdot 5 \mathrm{~cm}$. thick. Its nearest affinity is with $C$. orirubra.

Calostoma insignis (Berk.), Mass. Plate III, Figs. $35,3^{6 .}$

Exoperidium ochraceous, broken into irregular lobes, which sometimes remain attached to the middle of the stem-like base. Endoperidium, smooth, ochraceous, ostiolum pale green, teeth $5-8$, erect. Spore-sac pale green, spores globose coarsely spinulose, pale ochraceous, I4-I $7 \mu$ diameter. Stemlike base cylindrical or ventricose, smooth or lacunose.

Husseia insignis, Berk. in Hook. Lond. Journ. Bot. vol. vi, p. 508, Tab. I7 and I 8, f. 3, a, b, Tab. I9, f. I, a (I847); Sacc. Syll. v. 7. n. 2co. (Type in Herb. Berk. Kew, n. 4478.) Adam's Peak, Ceylon; and south of the island (Gardner), Borneo.

Endoperidium $1 \cdot 5^{-2} \mathrm{~cm}$. diameter, stem-like base $3^{-4} \mathrm{~cm}$. long by $\cdot 5^{-1} \mathrm{~cm}$. thick when ventricose.

C. pachystelis (Ces.), Mass.

Exoperidium thick, irregularly ruptured, and persistent at the base of the stem. Endoperidium globose, mouth umbonate, furnished with teeth.

Husseia pachystelis, Cesati, Mycetum in itinere Borneensi lecti ab O. Beccari descrip. p. 13, with fig.; Sacc. Syll. v. 7. n. 201. Sarawak, Borneo (Beccari).

The largest species of the genus. Exoperidium nearly $\mathrm{I} \mathrm{cm}$. thick, from $5-7 \mathrm{~cm}$. across when ruptured; endoperidium little more than $2 \mathrm{~cm}$. in diameter; stem $4-5 \mathrm{~cm}$. long by $1 \cdot 5-2 \mathrm{~cm}$. thick, internally lacunose, externally furrowed. Evidently a good Calostoma; the spore-sac appears to have disappeared from the endoperidium in the mature specimens, and is represented as filling the cavity of the latter in the section given by Cesati, which is evidently an immature plant with the thick exoperidium still continuous over the endoperidium, and Cesati says, 'Gleba sporifera totum peridium replens in fungo juvenili vel adhuc clauso.' No mention is made of the form of the spores, which, judging from affinity and locality, were presumably spherical. 
Calostoma cinnabarinum (Desv.) Plate III, Figs. 6-8.

Exoperidium vermilion inside, becoming dingy red, separating at the base like a calyptra, or breaking into irregular lobes at the apex. Endoperidium subglobose, ochraceous, ostiolum vermilion, teeth 5-7. Spore-sac very pale ochre, spores elliptic-oblong, minutely verruculose, pale ochre, I 5-I $8 \times 8$-1о $\mu$. Stem-like base variously lacunoso-reticulate. Desvaux, Journ. de Bot., tom. ii. (I 809), p. 94.

Gyropodium coccineun, Hitchcock, Sillim. Amer. Journ., vol. ix. (1 825), p. 56, pl. 3 .

Lycoperdon heterogeneum, Bosc, in Berl. Mag., v. p. 87, t. 6, f. $10 a, b$.

Lycoperdon callostoma, Poir, Encycl. suppl., v. 476.

Scleroderma callostoma, Pers., in Desv. Journ. de Bot., vol. ii. p. $I_{5}$, pl. 2 , f. 2.

Mitremyces heterogeneus, Nees, Pilze und Schwämme, p. I36, t. xii, f. $129 a(1817)$.

Mitremyces lutescens, Schweinitz, Syn. Carol. n. 345, t. 2, f. I; Nees, Syst. der Pilze, Pl. II ; Fr. S. M. 3. 64 ; Sacc. Syll. n. 202. Mitremyces cinnabarinum, Schw. Syn. Fung. Amer. Bor. in Amer. Phil. Soc., p. 255 (1831); Exs. Ellis, N. Amer. Fung. n. 727; Sacc. Syll. 7. n. 208; the Kew copy contains a beautiful specimen in the young state, with the bright red exoperidium continuous, and the stem-like base rudimentary. (Specimen from Schweinitz, in Hb. Bk., Kew ${ }^{1}$ ) On the ground. United States, New Granada. Endoperidium I-2 $\mathrm{cm}$. in diameter; stem $2-5 \mathrm{~cm}$. long, $1-2 \mathrm{~cm}$. thick.

Calostoma Ravenelii (Berk.), Mass. Plate III, Figs. 26, 27. Exoperidium becoming broken up into irregular warts, which often remain attached to the subglobose, ochraceous, endoperidium; mouth vermilion, teeth 4-5; spore-sac pallid, spores elliptic-oblong, smooth, colourless, I 5-1 $7 \times 8-9 \mu$. Stemlike base, short.

Mitremyces Ravenelii, Berk. in Trans. Linn. Soc., vol. xxii.

1 The bracketted refercnce indicates the value and locality of the specimen from which measurements, drawings, \&c. have been taken. 
( $18_{57}$ ), p. 130 , tab. 25 B; Sacc. Syll. 7. n. 203. (Type in Herb. Berk., Kew, n. 4473.) On the ground, Caesar's Head; mountains of South Carolina (Ravenel).

Endoperidium $\cdot 5^{-1} \mathrm{~cm}$. in diameter; stem-like base less than I cm. long. Berkeley's measurements are in all instances taken from dried specimens, and consequently rather smaller than mine, which are taken from specimens that have been moistened. Agreeing with C.lurida in size, and in the smooth elliptical spores.

Calostoma fusca (Berk.), Mass. Plate III, Fig. 24.

Simple or caespitose. Exoperidium dark brown externally, dingy red within. Endoperidium pale brown, subglobose, ostiolum vermilion, teeth erect, and forming an umbo before expansion, 4-6 in number. Spore-sac white, spores ellipticoblong, minutely verruculose, pallid. Stem-like base stout, elongated, brown, costato-lacunose.

Mitremyces fuscus, Berk. in Ann. Nat. Hist., vol. iii. (1839), pp. 325-326, Pl. vii, f. I; Sacc. Syll. v. 7. n. 206. (Type in Herb. Berk., Kew, n. 4474.)

Mitremyces australis, Berk. in Herb. Tasmania (Archer), (Gunn); near Melbourne, Australia (Berggren); Lake Muir, Australia (Muir).

Solitary or in clusters, two or three springing from a common base. The whole plant is of a dark brown colour, endoperidium from $I-I .5 \mathrm{~cm}$. in diameter, stem-like base $2-3 \mathrm{~cm}$. long by $\mathrm{I} \mathrm{cm}$. thick. Most nearly allied to $C$. lutescens, with which it agrees in the mode of separation of the exoperidium.

Calostoma lurida (Berk.), Mass. Plate III, Fig. 19.

Exoperidium breaking up early into small blackish granules, which remain attached to the ochraceous, subglobose endoperidium; ostiolum black internally, as well as the margins of the 4-5 teeth. Spore-sac pale ochre or whitish, spores ellipticoblong, smooth, pallid, 16-20 $\times 7-9 \mu$. Stem-like base short, brown, irregularly lacunose.

Mitremyces huridis, Berk. in Hook. Journ. Bot., vol. iv.(1845), 
pp. 65, 66, tab. I, f. 5 ; Sacc. Syll. v. 7. n. 205. (Type in Herb. Berk., Kew, n. 4475.) On sandy soil, Swan river, Australia (Drummond).

In the text Berkeley has called the above species $M$. luridis, on the plate it is called M. lucidus, and in the description of the plate $M$. luvidens, hence three names are given to the plant in the original description.

The exoperidium disappears very early, the small persistent wart-like remains showing little or no structure. Endoperidium about $\mathrm{I} \mathrm{cm}$. in diameter; stem-like base $\mathrm{I} \mathrm{cm}$. or less in length, and evidently more or less mucilaginous when growing, as it is studded with firmly imbedded grains of sand, and fragments of various kinds. Allied to $C$. Ravenelii, but readily distinguished from this and every other known species by the black ostiolum.

\section{EXPLANATION OF FIGURES ON PLATE III,}

Illustrating Mr. Massee's Monograph of the genus Calostoma, Desv.

Fig. I. Very young specimen of Calostoma cimnabarinum, showing the mucilaginous external volva, $a$; and the cord-like mycelium, $b$. Nat. size, after being soaked for some time in water.

Fig. 2. Vertical section of Fig. I, after removal of the volva; the thin red line is the commencement of differentiation of the exoperidium. Nat. size.

Fig. 3. Transverse section of Fig. I. Nat. size.

Fig. 4. Older specimen of C. cinnabarinum; the volva has disappeared and the exoperidium is continuous over every part. At this stage the spores are mature, but the spore-sac still completely fills the endoperidium. Nat, size.

Fig. 5. Transverse section of Fig. $4 ; a$, exoperidium; $b$, endoperidium ; $c$, sporesac; $d$, gleba. Nat. size.

Figs. $6,7,8$. Mature condition of $C$. cimnabarinum; $a$, remains of exoperidium; $b$, endoperidium ; $c$, spore-sac extruded. Nat. size. 6, drawn from a dry specimen; 7,8 , after soaking in water.

Fig. 9. Ostiolum of Fig. 7. $\times$ about 10 diam.

Fig. Io. Diagrammatic representation of the structure of the umbo in vertical section; $a$, exoperidium; $b$, endoperidium; $c$, core of red tissue that eventually becomes disorganised and forms the centre of the ostiolum passing vertically through the umbo of the endoperidium; $d$, spore-sac; $e$, ostiolum and surrounding portion of spore-sac which remains in contact with the endoperidium after contraction of the lower portion. 
Fig. II. C. cinnabarinum, section through exoperidium, $a$; endoperidium, $b$; and spore-sac, $c ; d$, mucilaginous matrix towards outside of exoperidium; $e$, a few spores that have become mixed with the hypha forming the spore-sac. $\times 400$ diam.

Fig. 12. Portion of a thread from the red zone between exoperidinm and endoperidium during the first stage of disintegration, indicated by the appearance of numerous minute red granules in the substance of the wall. $\times$ yoo diam.

Fig. I3. Hypha showing clamp-connections from exoperidium of C. cinnabarinum. $\times 400$ diam.

Fig. 14. Basidia with spores of $C$. cinnabarinum, $a$, rudimentary wart-like sterigmata. $\times 400$ diam.

Fig. I5. Free spores of $C$. cinnabarinum, showing the various forms. $\times 400$ diam.

Fig. I6. Portion of one of the coiled hypha that cause the contraction of the inner peridium in C. cinnabarinum. $\times 400$ diam.

Fig. I7. Same as Fig. 16, after being treated with dilute potassic hydrate. $\times 400$ diam.

Fig. 18. Portion of mouth and upper portion of spore-sac of C. cinnabarimum, showing teeth, $a$; and depressed circumscribing zone, $b . \quad \times$ about 4 times.

Fig. 19. C. lurida. Nat. size (after being moistened).

Fig. 20. Spores of Fig. 19. $\times 400$ diam.

Fig. 21. C. Junghuhni. Nat. size (after soaking).

Fig. 22. Vertical section of $C$. Junghuhni; $a$, endoperidium; $b$, spore-sac contracted. Slightly enlarged.

Fig. 23. Spores of C. Junghuhni. $\times 400$ diam.

Fig. 24. C. fusca; at $a$, the exoperidium shows the circumscissile mode of rupture. Nat. size (after soaking).

Fig. 25. Spores of C. fusca. $\times 400$ diam.

Figs. 26, 27. C. Ravenelii in different stages of development. Nat. size (moistened).

Fig. 28. Spores of C. Ravenelii. $\times 400$ diam.

Fig. 29. C. viridis. Nat. size (after being moistened).

Fig. 3o. Spores of $C$. viridis. $\times 400$ diam.

Fig. 31. C. rir bra. Nat. size (moistened).

Fig. 32. Spores of C. orirubra. $\times 400$ diam.

Fig. 33. C. Berkeleyi. Nat. size (moistened).

Fig. 34. Spores of C. Berkeleyi. $\times 400$ diam.

Figs. 35, 36. C. insignis; $a$, ruptured exoperidium. Nat. size (moistened).

Fig. 37. Vertical section of $C$. insignis; $a$, endoperidium; $b$, spore-sac in contracted state. Slightly enlarged.

Fig. 38. C. insignis; endoperidium with spore-sac, $a$, extruded. Nat. size.

Fig. 39. Spore of C. insignis. $\times 400$ diam.

Fig. 4o. Cluster of acicular crystals of oxalate of lime from gleba of $C$. insignis. $\times 700$ diam. 


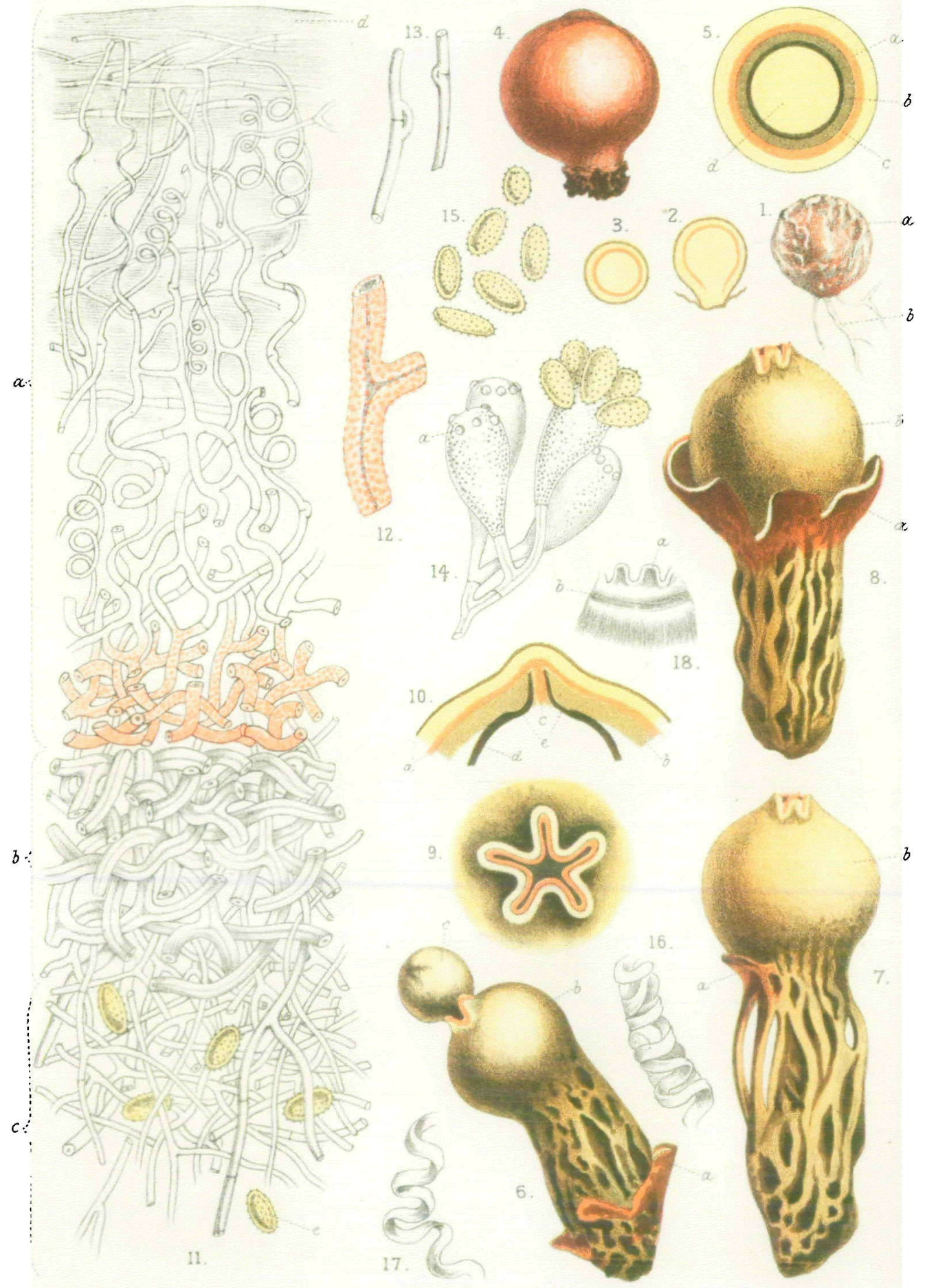



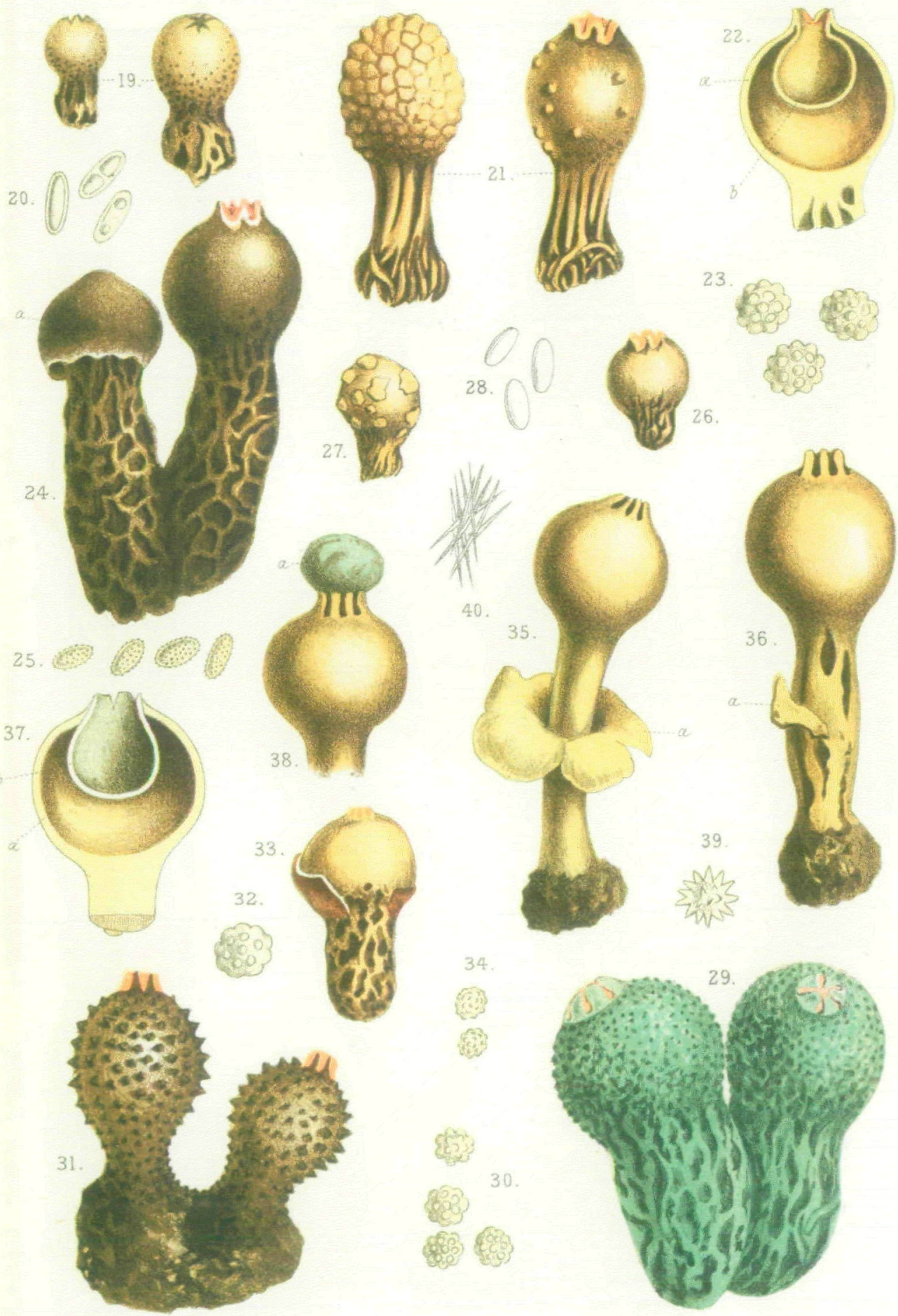


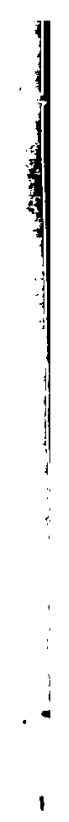

;

a' 